\title{
Respon Imun Itik Bali Pascavaksinasi Newcastle Disease
}

\author{
(IMMUNE RESPONSE OF BALI DUCK POST VACCINATION AGAINST NEWCASTLE \\ DISEASE)
}

\author{
Anindya Novitasari ${ }^{1 *}$, Ida Bagus Kade Suardana², I Putu Sampurna ${ }^{3}$ \\ ${ }^{1}$ Praktisi Dokter Hewan Kabupaten Situbondo, Jawa Timur. \\ ${ }^{2}$ Laboratorium Virologi Veteriner, Fakultas Kedokteran Hewan, Universitas Udayana, \\ Denpasar, Bali. ${ }^{3}$ Laboratorium Biostatistika Veteriner Fakultas Kedokteran Hewan, \\ Universitas Udayana, Denpasar, Bali. \\ *Email: anindyanovitasari2@gmail.com
}

\begin{abstract}
ABSTRAK
Penelitian ini bertujuan untuk mengetahui respon imun itik terhadap vaksinasi Newcastle Disease (ND), serta waktu yang diperlukan agar terbentuk titer antibodi yang protektif. Penelitian menggunakan rancangan acak lengkap (RAL) dengan waktu sebagai perlakuan. Objek penelitian menggunakan serum itik Bali. Pengambilan darah pravaksinasi dilakukan pada umur tiga minggu, pada umur empat minggu dilakukan vaksinasi secara sub kutan. Pengambilan darah pascavaksinasi dilakukan empat kali dengan interval waktu satu minggu, diambil dari vena tibialis cranial dengan spuite satu cc, dan serum dipindahkan ke dalam tabung Eppendorf. Titer antibodi diuji dengan uji Hemaglutination inhibition (HI), dan dinyatakan dalam Geometric Mean Titer (GMT) dengan satuan Log 2. Rerata titer antibodi pravaksinasi adalah $0,83 \pm 0,408 \log 2$. Sedangkan rerata titer antibodi minggu ke-1,2,3 dan 4 pasca vaksinasi adalah $2 \pm 0,632 \log 2,5,5 \pm 1,225 \log 2,1,2 \pm 0,983 \quad \log 2$, dan $0,16 \pm 0,408 \log 2$. Dapat disimpulkan titer antibodi protektif $\left(>2^{4}\right)$ pada minggu ke-2 pascavaksinasi.
\end{abstract}

Kata kunci: Newcastle Disease; vaksin aktif ND La-sota; titer antibodi

\section{ABSTRACT}

The purpose of this research was to know immune response of local bali duck post vaccination against Newcastle Disease, as well as the time required to form protective antibody titer. The research used completely randomized design with time as a treatment. The object of research was the serum of local bali duck. Blood was taken when pre-vaccination was done at aged three weeks old of the local Bali ducks, and then at the aged of four weeks old, vaccination was done subcutaneously. Post vaccination blood collection was performed four times in every oneweek intervals. The blood was taken from the cranial tibial vein by using $1 \mathrm{cc}$ syringe. The serum was transferred to the Eppendorf tube. Then the antibody against Newcastle Disease titers were tested by using Hemaglutination inhibition (HI) test and expressed in Geometric Mean Titer (GMT) with units of Log 2. Antibody titer examination pre-vaccination was $0.83 \pm 0.408 \log 2$. The mean of antibody titer at the first, second, third, and fourth week were $2 \pm 0.632 \log 2,5.5 \pm 1.225 \log 2,1.2 \pm 0.983 \log 2$, dan $0.16 \pm 0.408 \log 2$ respectively. The highest titer as well as was protective of the were reached in the second week post vaccination.

Keyword: Newcastle Disease; ND La-sota active vaccine; antibody titer

\section{PENDAHULUAN}

Usaha peternakan itik semakin diminati sebagai alternatif sumber pendapatan bagi masyarakat di pedesaan maupun di sekitar perkotaan, sebagai akibat munculnya penyakit flu burung yang sangat merugikan peternakan ayam ras maupun ayam buras. Di Indonesia tersedia beberapa jenis itik yang diberi nama sesuai dengan asal daerah pengembangannya, seperti: itik Tegal,
Alabio, Mojosari, Bali dan yang lainnya. Ternak itik mempunyai beberapa keunggulan dibandingkan dengan ternak ayam, seperti nilai jual telur lebih mahal daripada telur ayam, ternak itik lebih mampu mencerna ransum dengan serat kasar yang lebih tinggi sehingga harga pakan bisa lebih murah dan produktivitas telur lebih tinggi dibandingkan dengan ayam kampung (Prasetyo, 2006). 
Salah satu kendala yang sering dihadapi dalam usaha peternakan itik adalah serangan penyakit yang salah satunya terserang Newcastle Disease (ND). ND merupakan penyakit yang sangat merugikan bagi industri peternakan unggas (Shunlin et al., 2010) dan pertama kali ditemukan oleh Doyle pada tahun 1926 di daerah Newcastle (Inggris) selanjutnya diberi nama Newcastle Disease sesuai dengan daerah ditemukannya penyakit tersebut. Pada tahun yang sama virus ND juga telah diisolasi di Bogor. Newcastle Disease dikenal dengan berbagai nama di antaranya pseudo-fowl pest, avian pest, avian distemper, Tetelo disease, pseudovogel-pest, pseudo-poultry plaque, Korean fowl plaque, Ranikhet disease, Atypische Geflugelpest, dan avian pneumoencephalitis (Alexander, 2003).

Unggas yang dapat terserang oleh virus ND adalah ayam, itik, dan kalkun (Adi et al., 2008). Ayam merupakan unggas yang paling peka terhadap ND dibandingkan dengan unggas lainnya (Abdelrhman et al., 2013). Itik dan kalkun yang terinfeksi ND jarang menunjukkan gejala klinis namun sangat berpotensi sebagai penyebar virus pada unggas rentan yang ada disekitarnya, sehingga itik dan kalkun disebut reservoir alami dari virus ND (Kencana, 2012).

Cara pemeliharaan itik di Bali kebanyakan dengan sistem ekstensif atau semi intensif. Sistem pemeliharaan semi intensif yakni dengan cara mengembalakan itik secara berpindah-pindah dari satu hamparan sawah pascapanen ke hamparan sawah pascapanen lainnya (Alexander, 2001). Cara pemeliharaan seperti ini berpotensi untuk menyebarkan virus ND dari satu daerah ke daerah yang lainnya. ND dapat diatasi dengan dilakukan vaksinasi. Namun, sampai saat ini kasus ND belum bisa diatasi dengan tuntas. Peternak itik masih jarang melakukan vaksinasi ND karena ND pada itik jarang menunjukkan gejala klinis,

Penelitian ini bertujuan untuk mengetahui respon imun itik Bali pascavaksinasi Newcastle Disease, serta waktu yang diperlukan hingga terbentuknya titer antibodi protektif.

\section{METODE PENELITIAN}

\section{Bahan Penelitian}

Penelitian ini menggunakan antigen ND empat unit HA virus standar ND Balitvet (Bogor), serum itik Bali sebanyak 30 sampel, Phosphate Buffer Saline (PBS) $\mathrm{pH}$ 7,2-7,4 dan suspensi eritrosit $0,1 \%$. Penelitian ini menggunakan vaksin Newcastle Disease (ND La Sota) aktif (live vaccine) yang diproduksi oleh PT Medion Farma Jaya Bandung - Indonesia.

\section{Hewan Coba}

Hewan yang digunakan dalam penelitian adalah itik Bali betina sehat umur tiga minggu yang belum divaksinasi sebanyak enam ekor. Semua itik didapat dari peternakan milik Bapak Fendy Sutrisna berlokasi di Desa Kalianget, Kecamatan Seririt, Kabupaten Buleleng.

\section{Rancangan Penelitian}

Pengambilan sampel dilakukan pada minggu ke 0, 1, 2, 3, dan 4 pascavaksinasi. Setiap pengambilan diambil 6 sampel dan total sampel yang diambil sebanyak 30 sampel. Penelitian ini menggunakan rancangan acak lengkap (RAL) dengan waktu sebagai perlakuan. Sebelum pengambilan sampel dilakukan terlebih dahulu diberikan vaksin Newcastle Disease (ND) aktif pada itik Bali umur 4 minggu.

\section{Pengumpulan Sampel Serum}

Pengambilan darah itik betina bali dilakukan sebanyak lima kali yaitu satu kali pravaksinasi dan empat kali pasca vaksinasi. Darah diambil dari vena tibialis cranial dengan menggunakan spuite $1 \mathrm{ml}$ tanpa antikoagulan. Darah dibiarkan membeku dalam suhu kamar sampai serumnya keluar. Serum yang masih bercampur dengan sel darah merah di sentrifugasi dengan kecepatan $2500 \mathrm{rpm}$ selama 10 menit, kemudian dipisahkan ke dalam tabung Eppendorf, dan disimpan pada suhu $-20^{\circ} \mathrm{C}$ sampai saat digunakan. 


\section{Uji Hambatan Hemaglutinasi/HI}

Untuk mengetahui tingkat kekebalan suatu hewan dapat diketahui melalui pengukuran titer antibodi dengan uji $\mathrm{HI}$ titrasi. Kedalam microplate dasar U diisi dengan 0,025 ml PBS pada setiap lubang (1-12), lubang pertama dan kedua diisi dengan serum yang selanjutnya diencerkan secara seri kelipatan dua dari lubang kedua sampai kesepuluh dengan microdiluter. Pada lubang (1-11) ditambahkan 0,025 ml suspensi antigen empat unit HA, sedangkan pada lubang 12 hanya diisi $0,025 \mathrm{ml}$ PBS kemudian diayak selama 30 detik dan diinkubasikan dalam suhu kamar selama 30 menit. Pada setiap lubang (1-12) ditambahkan $0,05 \mathrm{ml}$ suspensi eritrosit $1 \%$ dan diayak kembali selama 30 detik. Microplate diinkubasikan pada suhu kamar selama 1 jam dan diamati setiap 15 menit untuk mengetahui ada tidaknya reaksi aglutinasi eritrosit. Hasil uji HI positip ditandai dengan adanya endapan pada dasar microplate atau tidak ada aglutinasi (Suardana et al., 2009)

\section{HASIL DAN PEMBAHASAN}

Rataan titer antibodi pada setiap pengambilan sampel serum (P0, P1, P2, P3, P4) disajikan dalam Tabel 1. Pada minggu ke-1 mengalami peningkatan yang nyata $(\mathrm{P}<0,05)$ dengan minggu ke- 0 , minggu ke2 mengalami peningkatan yang sangat nyata $(\mathrm{P}<0,01)$ dengan minggu ke-1. Sedangkan pada minggu ke-3 mengalami penurunan yang sangat nyata $(\mathrm{P}<0,01)$ dengan minggu ke-2 namun tidak berbeda nyata $(\mathrm{P}>0,05)$ dengan kontrol (minggu ke$0)$, minggu ke-4 mengalami penurunan yang tidak nyata $(\mathrm{P}>0,05)$ dengan minggu ke-3 namun tidak berbeda nyata $(\mathrm{P}>0,05)$ dengan kontrol.

Hasil pemeriksaan titer antibodi pravaksinasi itik adalah $0,83 \log 2$, yang berarti di dalam tubuh itik Bali masih terdapat maternal antibodi. Maternal antibodi pada anak itik menurun sampai umur 20 hari (Winddi et al., 2016). Pemeriksaan pravaksinasi bertujuan untuk mengetahui ada atau tidaknya maternal antibodi pada tubuh itik, karena jika maternal antibodi tinggi dapat menyebabkan pembentukan antibodi yang kurang optimal, karena maternal antibodi akan menetralisir antigen vaksin (Okwor et al., 2014). Respon antibodi yang protektif sesuai dengan standar ASEAN untuk vaksin ND adalah lebih besar dari (1:16) $\log 2$ atau $4 \log 2$ (ACFAF, 2012).

Tabel 1. Rerata GMT ND itik Bali $(\log 2)$

\begin{tabular}{cccc}
\hline \multirow{2}{*}{$\begin{array}{c}\text { Minggu } \\
\text { sampling }\end{array}$} & $\begin{array}{c}\text { Rerata Titer } \\
\text { Antibodi ND } \\
(\log 2)\end{array}$ & \multicolumn{2}{c}{ Sig. } \\
\cline { 3 - 5 } 0 & $0,83 \pm 0,408$ & $\mathrm{ab}$ & $\mathrm{ab}$ \\
1 & $2,00 \pm 0,632$ & $\mathrm{c}$ & $\mathrm{b}$ \\
2 & $5,50 \pm 1,225$ & $\mathrm{~d}$ & $\mathrm{c}$ \\
3 & $1,17 \pm 0,983$ & $\mathrm{bc}$ & $\mathrm{ab}$ \\
4 & $0,16 \pm 0,408$ & $\mathrm{a}$ & $\mathrm{a}$ \\
\hline
\end{tabular}

Ket: Huruf (superskrip) yang berbeda nyata menunjukkan nilai yang berbeda sangat nyata $(\mathrm{P}<0,01)$, sebaliknya huruf yang sama menunjukkan nilai yang tidak berbeda nyata $(\mathrm{P}>0,05)$.

Pada minggu ke-1 pascavaksinasi menunjukkan rerata titer antibodi tidak mengalami peningkatan yang signifikan. Pada minggu ke-1 pascavaksinasi, vaksin aktif ND La-Sota yang digunakan telah mampu merangsang pembentukan antibodi dengan rerata titer antibodi ND $2 \pm 0,632 \mathrm{log}$ 2. Titer antibodi minggu ke- 1 pascavaksinasi menunjukkan titer antibodi yang masih rendah, hal tersebut dikarenakan respon kekebalan terhadap vaksin yang diberikan baru mulai terbentuk dan tubuh masih dalam proses pengenalan terhadap antigen yang masuk ke dalam tubuh (Kencana et al., 2015). Pada minggu ke-2 pascavaksinasi menunjukkan rerata titer antibodi yang sangat nyata $(\mathrm{P}<0,01)$ dan merupakan titer puncak selama penelitian. Pada minggu ke-2 pascavaksinasi, vaksin aktif yang digunakan telah mampu merangsang terbentuknya titer antibodi yang protektif 
terhadap ND dengan rerata titer antibodi $5,5 \pm 1,225 \log 2$. Hal ini sesuai dengan penelitian yang dilakukan oleh Dewi (2011) pada ayam petelur dengan pemberian vaksin aktif ND-IB yang menunjukkan adanya peningkatan titer antibodi minggu ke-2 pascavaksinasi.

Pada minggu ke-3 dan minggu ke-4 pascavaksinasi menunjukkan rerata titer antibodi mengalami banyak penurunan dan tidak protektif yaitu $1,17 \pm 0,983 \log 2$ dan $0,16 \pm 0,408 \log 2$. Hal ini sesuai dengan sifat dari vaksin yang digunakan yaitu vaksin aktif, yang mempunyai durasi lebih pendek dibandingkan dengan vaksin inaktif (Aiyer et al., 2013). Pada minggu ke-3 dan minggu ke-4 pascavaksinasi terjadi fase penurunan yang disebabkan oleh adanya waktu paruh antibodi yakni waktu yang dibutuhkan titer antibodi untuk berkurang setengahnya dari titer antibodi awal. Selain itu, penurunan titer antibodi juga terjadi akibat tantangan agen penyakit di lapangan (Kencana et al., 2016). Pembentukan titer antibodi pada saat vaksinasi primer tidaklah setinggi vaksinasi booster dan relatif tidak bertahan lama karena pada saat vaksinasi pertama di dalam tubuh hewan baru terbentuk sel memori (Banu et al., 2009).

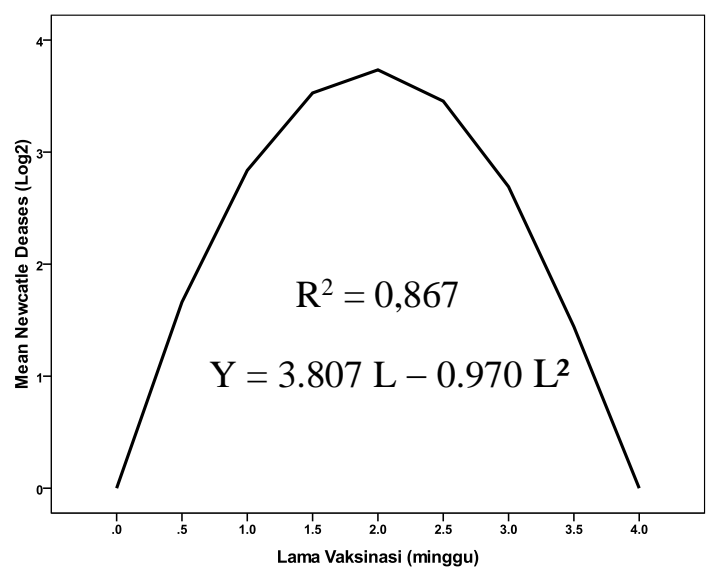

Gambar 1. Grafik persamaan garis titer antibodi ND

Hasil analisis regresi menunjukkan bahwa garis persamaan $\mathrm{Y}=3,807 \mathrm{~L}-0,970 \mathrm{~L}^{2}$. Nilai $\mathrm{Y}$ merupakan rata-rata titer antibodi Newcastle Disease (ND) yang dinyatakan dengan Geometric
Mean Titer (GMT) dan L merupakan variabel regresi yang menyatakan waktu (minggu) pra dan pascavaksinasi. Grafik persamaan garis titer antibodi ND pravaksinasi dan pascavaksinasi disajikan dalam Gambar 1.

Berdasarkan persamaan garis regresi diatas dapat diketahui titer antibodi protektif pada minggu ke-2 dan pada minggu ke-3 pascavaksinasi merupakan titer antibodi yang tidak protektif sehingga vaksinasi ulangan (booster) hendaknya dilakukan pada minggu ke-3 pascavaksinasi atau pada saat itik umur 7 minggu. Dapat disimpulkan bahwa waktu pengambilan sampel setiap minggunya mempunyai hubungan erat terhadap perubahan titer antibodi ND. Hal tersebut dapat dilihat dari nilai $\mathrm{R}^{2}$ yang mendekati 1 yaitu 0,867 .

\section{SIMPULAN DAN SARAN}

\section{Simpulan}

Titer antibodi itik Bali yang divaksinasi menggunakan vaksin aktif La-Sota, terjadi peningkatan titer pada minggu ke-1 dan ke2 dan terjadi penurunan pada minggu ke-3 dan ke-4 pascavaksinasi. Rerata titer antibodi yang protektif terjadi pada minggu ke-2 pascavaksinasi dengan rerata titer antibodi sebesar 5,5 $\pm 1,225 \log 2$.

\section{Saran}

Untuk mendapatkan imunitas yang cukup maka hendaknya dilakukan booster (vaksinasi ulangan) pada minggu ke-3 pascavaksinasi pertama.

\section{DAFTAR PUSTAKA}

ASEAN Cooperation in Food, Agriculture and Forestry (ACFAF). 2012. ASEAN Standards for Animal Vaccines, Second Edition. Livestock Publication. Series. http:/www.asean.org/communities/asea neconomiccommunity/category/public ation-3. (2 Mei 2016)

Abdelrhman SS, Rihan EEM, Almotairy HM, Jassem AHA, Al-Blowi M. 2013. Sero-Virological Studies on Newcastle Disease and Avian Influenza in Farmed 
Ostriches (Struthio camelus) in Saudi Arabia. J. World's Poult. Res. 3(2): 3842.

Adi AAAM, Astawa NM, Putra KSA, Matsumoto Y. 2008. Deteksi Virus Penyakit Tetelo Isolat Lapangan dengan Metode Nested Reverse Transcriptase-Polymerase Chain Reaction. J. Vet. 9(3): 128-134.

Adi AAA, Astawa NM, Putra KSA, Hayashi, Matsumoto Y. 2010. Isolation and Characterization of a Pathogenic Newcastle disease Virus from a Natural Case in Indonesia. J. Vet. Med. Sci. 72(3): 313-319.

Aiyer HP, Ashok KHG, Kumar GP,Shivakumar N. 2013. An Overview of Immunologic Adjuvants-A Review. J. Vaccines Vaccine. 4(1): 1-4.

Alexander DJ. 2001. Newcastle Disease. The Gordon Memorial Lecture. Br. Poult. Sci. 42: 5-22.

Alexander DJ. 2003. Newcastle Disease, Other Avian Paramyxoviruses, and Pneumovirus Infections. Di dalam: Frank Jordan et al., Editor. Disease of Poultry. Edisi ke-11. Blackwell Publishing. Pp: 63-81.

Banu NA, Islam MS, Chowdhury MMH. 2009. Determination of Immune Response of Newcastle Disease Virus. J. Bangladesh Agric. Univ. 7(2): 329334.

Dewi MK. 2011. Perbedaan nilai optical density $405 \mathrm{~nm}$ antibodi pada ayam layer yang divaksin Infectious Bronchitis aktif monovalen dengan vaksin Infectious Bronchitis aktif bivalen (IB-ND) menggunakan indirect ELISA (artikel ilmiah). Surabaya, Universitas Airlangga.

Kencana GAY, Kardena IM, Mahardika IGNK. 2012. Peneguhan Diagnosis
Penyakit Newcastle Disease Lapang pada Ayam Buras di Bali Menggunakan Teknik RT-PCR. J. Kedokteran Hewan. 6(1): 28-31.

Kencana GAY, Suartha IN, Simbolon MP, Handayani AN, Ong S, Syamsidar, Kusumastuti A. 2015. Respons Antibodi terhadap Penyakit Tetelo pada Ayam yang Divaksin Tetelo dan Tetelo-Flu Burung. J. Vet. 16(2): 284287.

Kencana GAY, Suartha IN, Paramita NMAS, Handayani AN. 2016. Vaksin Kombinasi Newcastle Disease dengan Avian Influenza Memicu Imunitas Protektif pada Ayam Petelur terhadap Penyakit Tetelo dan Flu Burung. J. Vet. 17(2): 264-271.

Okwor GO, El-Yuguda A, Baba SS. 2014. Profile of Maternally Derived Antibody in Broiler Chicks and In-Ovo Vaccination of Chick Embryo against Newcastle Disease. WJV. 4(1): 72-80.

Prasetyo LH. 2006. Strategi dan Peluang Pengembangan Pembibitan Ternak Itik. Wartazoa. 6(3): 109-115.

Shunlin H, Tongyan W, Yuliang L, Chun M, Xiaoquan W, Yantao W, Xiufan L. 2010. Identification of a Variable Epitope on the Newcastle Disease Virus Hemagglutinin-Neuraminidase Protein. J. Vet. Microbiol. 140(2): 92-97.

Suardana IBK, Dewi NMRK, Mahardika IGN. 2009. Respon Imun Itik Baliterhadap Berbagai Dosis Vaksin Avian Influenza H5N1. J. Vet. 10(3): 150-155.

Winddi A, Purnama ES, Sri S. 2016. Pengaruh Pemberian Dosis Vaksin AI (Avian Influenza) Inaktif pada Itik Betina terhadap Titer Antibodi yang Dihasilkan. J. Ilmiah Peternakan Terpadu. 4(2): 140-142. 